\title{
HBx对HBV复制的调控
}

郭艳丹 ${ }^{1}$, 汪静雯 ${ }^{1}$, 袁森 $^{1}$, 郭舒婷 ${ }^{1}$, 刘 丹 $^{1}$, 孙桂鸿 ${ }^{1,2 *}$

1. 武汉大学基础医学院, 武汉 430072;

2. 湖北省过敏及免疫相关疾病重点实验室, 武汉, 430072

*联系人, E-mail: ghsunlab@whu.edu.cn

2019-07-02 收稿, 2019-07-26 修回, 2019-07-29 接受, 2019-09-16 网络版发表 国家自然科学基金(81572447)资助

摘要乙型肝炎病毒(HBV)是导致肝细胞肝癌(HCC)发生发展的重要诱因之一. HBV在感染细胞后进行病毒DNA的 复制、病毒蛋白的合成以及新病毒颗粒的包装和释放等步骤, 其中病毒感染细胞逃避宿主免疫后, 就可能通过HBV 复制产生子代病毒、形成持续感染、诱导肝癌的发生发展. 机体中 HBV的复制受到多种因素的影响, 而乙型肝炎病 毒的X蛋白 $(\mathrm{HBx})$ 对于 HBV复制的影响是其中一个重要因素. 本文在对 HBx 蛋白的结构组成及其分布做简要阐述的 基础上, 重点综述HBx通过不同的修饰途径来调控 HBV 的复制, 以及HBx通过miRNA来调节HBV复制的进程.

关键词 HBx, HBV复制, cccDNA, miRNA

HBV 是不完全的双链DNA(也称为松驰环状DNA, $\mathrm{rcDNA}$ )病毒, 其负链是完全的, 但正链的长度仅有负链 的 $50 \% \sim 100 \%$, 不同的基因型其正链长度各不相同. $\mathrm{X}$ 基因序列在嗜肝病毒科中具有高度保守性，且具有重 要生物学功能. 虽然对X蛋白的研究不断深人, 许多研 究认为HBx通过参与不同信号途径来影响细胞增殖、 调亡、有丝分裂纺锤体形成和病毒复制等, 但其具体 功能和生物学意义尚有许多未解之谜, 而本文将着重 论述HBx对病毒复制的作用.

1993年研究发现旱獭肝炎病毒中X蛋白缺失后旱 獭肝炎病毒不能在旱獭体内进行复制, 研究人员据此 首次提出 X蛋白对病毒的复制具有重要作用这一观 点 ${ }^{[1]}$. 同时体内研究表明, 将X基因缺陷型的HBV转染 细胞后, 病毒复制水平仅为野生型HBV的 $10 \%$; 而缺少 $\mathrm{X}$ 基因的Woodchuck HBV 将无法在宿主细胞内完成病 毒复制过程; 相反, 在已转染HBV X蛋白表达基因的 HepG2细胞中, 病毒复制增加了 5 10倍. Tang等人 ${ }^{[2]}$ 将 各种 $H B x$ 基因缺陷型 $H B V$ 病毒转染 $H e p G 2$ 细胞, 结果 显示, $H B V$ 病毒复制和转录均受抑制. 尽管 $H B x$ 影响
$\mathrm{HBV}$ 复制的精细分子机制目前不是很清楚，但研究发 现HBx 对病毒的生命周期是必不可少的. 因此了解 $\mathrm{HBx}$ 在病毒生命周期中的作用, 特别是对 HBV复制的 影响, 对治疗HBV相关性肝脏疾病具有重要意义.

\section{$1 \mathrm{HBx}$ 的蛋白结构组成和分布}

$\mathrm{HBV}$ 基因组较小, 仅有 $3.2 \mathrm{~kb}$, 包含 4 个相互重叠的 开放阅读框(ORF), 而乙型肝炎病毒 $\mathrm{X}$ 基因由 $\mathrm{HBV}$ 最小 的一个 ORF所编码，位于 $\mathrm{HBV}$ 基因组的 $\mathrm{C}$ 基因上游 $1374 \sim 1836 \mathrm{bp}$ 之间，长465个核苷酸，其转录出的 mRNA长为 $0.7 \mathrm{~kb}$, 蛋白产物仅有 154 个氨基酸, $\mathrm{HBx}$ 蛋 白分子量大小约 $17 \mathrm{kD}$, 属于非结构蛋白. HBx具有 5 个 重要的结构域(如图1所示): (1) N端的负调控区, 与该区 域相结合的调控因子可以抑制 $\mathrm{HBx}$ 的活性; (2) 负调控 区附近的高变区; (3) 损伤DNA结合蛋白1(DDB1)结合 区; (4) 核输出信号区; (5) C-末端的转录因子结合区 ${ }^{[3]}$. 蛋白的结构决定其功能, 而 HBx 的结构也决定它可在 胞质和胞核中所发挥的不同作用.

关于 $X$ 蛋白的细胞内分布情况，首次报道于1998 


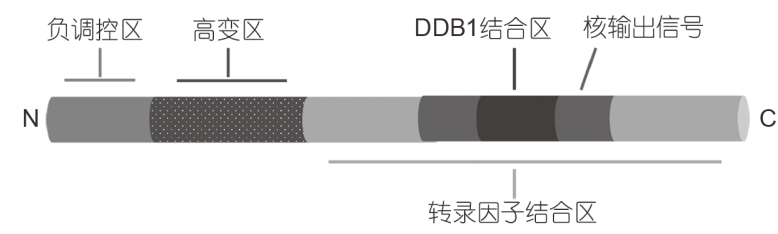

图 $1 \mathrm{HBx}$ 的蛋白结构组成

Figure 1 Modular organization of HBx

年, 作者研究了旱獭肝炎病毒(WHV)X蛋白(WHx)在持 续感染的旱獭肝细胞中的亚细胞分布. 体内标记和细 胞分离研究表明，WHx的分布与胞质骨架以及核骨架 相关 ${ }^{[4]}$. 继该研究之后, 有大量的研究表明, 不论是在 细胞中转染HBx或HBV质粒, 还是用HBV感染细胞, 检 测发现 $H B x$ 大多数定位在细胞质中, 而只有少量存在 于细胞核中 ${ }^{[5,6]}$. 有研究进一步阐明, 在表达量比较少 的情况下 $\mathrm{HBx}$ 主要定位在细胞核中，而随着表达量的 增加则主要定位在细胞质中; 该研究同时认为, $\mathrm{HBx}$ 是 留在细胞核还是细胞质中, 取决于 Crm-1依赖的核输出 信号的开关效应 ${ }^{[7]}$. 随着研究的深人, $\mathrm{HBx}$ 在细胞内分 布由细胞质精确到亚细胞器水平. 如Rahmani等人 ${ }^{[8]}$ 发 现, $\mathrm{X}$ 蛋白在胞质中主要分布于线粒体外膜, 作用于电 压依赖的阴离子通道(voltage dependent anion channel, VDAC), 具有干扰线粒体通透性转换孔(mitochondria permeability transition pore, MPTP)蛋白的功能, 可引 起线粒体跨膜电位改变和线粒体功能变化. Wang等 人 $^{[9,10]}$ 发现, $\mathrm{HBx}$ 与线粒体的细胞色素 $\mathrm{C}$ 氧化酶 III (cytochrome C oxidase subunit III, COX III)在肝细胞内相 互作用，而李丹等人 ${ }^{[11]}$ 进一步证实 $\mathrm{HBx}$ 与 $\mathrm{COX}$ III 是特 异性结合, 这些结果表明, HBx定位于胞质中的线粒体 上. 2014 年Liu课题组 ${ }^{[12]}$ 发现, HBV 通过HBx 与溶酶体 上的V-ATPase HD亚基结合，使质子不能被正常洜人 溶酶体腔内, 导致溶酶体酸性改变, 自噬体的降解能力 受到损害, 从而抑制HBV的降解, 维持细胞内的HBV水 平, 促进HBV形成慢性感染, 该实验结果表明 $\mathrm{HBx}$ 存在 于自噬溶酶体上. HBx的肝细胞内不同定位, 决定其具 有不同的功能. 胞质中的 $\mathrm{HBx}$ 主要参与调控胞内信号 通路, 而核内的 $\mathrm{HBx}$ 主要起反式激活作用, 可通过与一 些转录因子的相互作用, 如NF- $\kappa B, C R E B(c A M P$ response element binding protein), AP-1, TBP(TATAbinding protein)等, 通过这些转录因子调控下游靶基因 的表达, 实现调节HBV复制的功能.

但到目前为止，关于HBx的胞质和核内分布的详 细的分子机制依然需要进一步探索, 特别是HBx在胞
质和核内的分布对于 $H B x$ 如何影响HBV复制和致癌功 能, 需要更深人的研究.

\section{HBx 通过甲基化、乙酰化或泛素化修饰途 径来调控HBV复制}

在HBV感染过程中, HBV RcDNA人核, 首先形成 共价闭合环状DNA(cccDNA), 然后以 $\operatorname{cccDNA}$ 为模板转 录形成4种RNA, 进而翻译为合成完整病毒所需的多种 病毒蛋白. 但其中的pgRNA会重新逆转录为 $r c D N A$. 一 部分 rcDNA直接和病毒蛋白组装形成成熟病毒颗粒释 放出去, 而另一部分的rcDNA进一步形成 $c c c D N A$, 完 成下一复制周期. 研究表明, HBV的cccDNA目前不能 被有效清除, cccDNA的存在增强了HBV DNA的复制 能力，有利于 $H B V$ 发生持续的感染、炎症反应以及 $\mathrm{HBV}$ 产生的耐药性. 众所周知, HBV cccDNA是所有病 毒mRNAs转录的模板, cccDNA能与组蛋白、非组蛋 白、病毒蛋白和宿主蛋白以稳定的Episome形式聚集 在感染细胞的细胞核中. 而cccDNA特异性染色质免疫 共沉淀(ChIP)的定量分析表明, 在细胞核内, cccDNA与 组蛋白3(H3), H4和非组蛋白(如HBc, HBx)、宿主转录 因子等共同组成一个小分子复合物. 使用 $\operatorname{ccc}$ DNAChIP分析发现, 几个宿主细胞转录因子(CREB, ATF, YY1, STAT1和STAT2)和核染色质修饰酶(PCAF, p300/ CBP, HDAC1, SIRT1和EZH2)结合cccDNA. 这些结合, 预示在 $c c c D N A$ 上的结合蛋白，不仅可能通过不同修饰 来调控 $c c c D N A$ 影响 $\mathrm{HBV}$ 复制 ${ }^{[13]}$, 也可能通过结合的转 录因子来调控 $\mathrm{cccDNA}$ 的转录. 而 $\mathrm{HBx}$ 作为反式激活因 子, 可与转录因子协同作用直接调控 $\mathrm{cccDNA}$ 的转录. 例如: Tang等人 ${ }^{[14]}$ 发现, CRTC1(CREB-regulated transcriptional coactivator 1 )是 $\mathrm{HBV}$ 转录和复制所必需的. 其机制在于CRTC1与CREB相互作用可刺激 $\operatorname{ccc}$ 与NA上 $p r e S 2 / S$ 启动子的活性, 而 $\mathrm{HBx}$ 能稳定 CRTC 1 的表达, 因 而揭示了 $\mathrm{HBx}$ 与 $\mathrm{CREB}$ 和 CRTC1在促进HBV 转录和复 制中的重要作用. 另外, Gao等人 ${ }^{[15]}$ 揭示了 $\mathrm{HBx}$ 通过增 强FoxA1与MSL2启动子区上的FOXA1结合元件的结 合, 促进MSL2的转录和表达, 进而维持HBV cccDNA 的稳定性, 形成HBx/MSL2/cccDNA/HBV的正反馈环. 而 $\mathrm{HBx}$ 与转录因子协同调控 $\mathrm{cccDNA}$ 的转录, 是否涉及 不同的修饰, 目前也是大家关注的热点. 虽然文献显示 $\mathrm{HBx}$ 与甲基转移酶SMYD3相互作用，激活AP-1信号途 径，但该实验证明过表达或干扰SMYD3的表达都不影 响HBV转录 ${ }^{[16]}$. 在该研究中, 作者虽然探索了它们的 
相互作用，但并没有对SMYD3是否甲基化HBx或转录 因子进行深人研究, 特别是其行使的具体功能也没有 进一步探索.

虽然已有大量的文献报道, HBx在 $\operatorname{cccDNA}$ 的转录 和转录后的修饰中扮演了重要的角色 ${ }^{[17 ~ 20]}$, 但是许多 具体机制并不是非常清楚. 下面我们将对 $\mathrm{HBx}$ 通过甲 基化、乙酰化、泛素化等修饰影响cccDNA的转录，达 到实现调控HBV的复制的过程进行简要的综述.

\subsection{HBx 通过甲基化修饰来影响HBV复制}

研究发现, 在细胞核内, cccDNA转录受表观遗传 机制调控，如DNA甲基化、结合DNA的组蛋白和其他 调控因子的甲基化修饰等. DNA的高甲基化导致相关 基因的转录、表达降低甚至缺失，从而导致该基因功 能的异常. 在患者肝组织中发现, 整合在基因组染色体 上的HBV DNA、游离的HBV DNA和cccDNA都会被 甲基化，目前 $\mathrm{HBV}$ DNA被发现有6处 $\mathrm{CpG}$ 岛，而X基因 的启动子区和加强子 II就属于一处，该处的 $\mathrm{CpG}$ 岛超甲 基化导致 $\mathrm{HBsAg}$ 和 $\mathrm{HBeAg}$ 表达的减少或缺失．体外实 验证明，HBV DNA的甲基化与宿主的甲基化转移酶 (DNMT)有关，共转染宿主DNMT3a和HBV DNA时, $\mathrm{HBsAg}$ 和 $\mathrm{HBeAg}$ 表达明显减少 ${ }^{[21,22]}$. 同时 $\mathrm{Fu}$ 等人 ${ }^{[23]}$ 的 研究认为, HBx能上调DNMT3a/3b的表达, 促进下游靶 基因 $S O C S 1$ 启动子的 $\mathrm{CpG}$ 岛甲基化. 虽然有报道认为 PRMT5介导H4R3甲基化会招募DNMT3，但是该研究 并没有涉及 $\mathrm{HBV}^{[24]}$; 而文献[25]显示PRMT5 能结合 cccDNA，并认为它们的结合不是通过 $\mathrm{HBx}$, 而是 $\mathrm{HBe}$ 对PRMT5与 5 cccDNA的结合发挥了重要作用, 该研究证 明PRMT5能催化结合 cccDNA的H4的R3me2s，抑制 $\operatorname{cccDNA}$ 的转录. 虽然PRMT5不通过HBx 作用于 cccDNA，但另一项研究发现，与PRMT5同源的甲基转 移酶PRMT 1 则能与 HBx 相互作用，且 HBx 可抑制 PRMT1的甲基转移酶活性; ChIP分析显示, PRMT1可 被招募到HBV的 $\operatorname{cccDNA}$ 上，过表达PRMT1则抑制 HBV 的复制, 但这种抑制是赖于HBx的表达. 该文作者 认为, PRMT1抑制HBV的复制是通过PRMT1对靶基因 的甲基化实现的，尽管体外甲基化实验并没有检测到 PRMT1对HBx的甲基化，但是可能由于体外实验条件 导致，故并不能排除体内PRMT1对 $\mathrm{HBx}$ 甲基化的可 能 ${ }^{[26]}$. Rivière等人 ${ }^{[27]}$ 报道, HBx缓解了SETDB1组蛋白 甲基转移酶介导的 HBV cccDNA转录抑制，当HBV感 染时，SETDB1介导的组蛋白H3的9位赖氨酸三甲基化
(H3K9me3)增加，进而促进浓缩染色质相关的异染色 质蛋白1因子(HP1)的表达，它们共同调控染色体的结 构变化, 诱导HBV cccDNA的转录沉默, 但HBx蛋白可 以解除这种抑制作用，并且使 $c c c D N A$ 处于转录激活状 态 ${ }^{[27]}$

\section{$2.2 \mathrm{HBx}$ 通过乙酰化修饰来影响HBV复制}

除DNA和蛋白的甲基化外，cccDNA结合的组蛋白 3(H3)和H4或转录因子还会选择性地被乙酰化和去乙 酰化, 乙酰转移酶(HATs)和去乙酰化酶(HDACs)通过不 同的动力学被招募到 $\operatorname{cccDNA}$, 通过调控组蛋白状态, 对cccDNA发挥翻译后修饰功能. 如Belloni等人 ${ }^{[28]}$ 报道, cccDNA结合的H3/H4组蛋白乙酰化状态对HBV复制有 影响. 他们发现, 组蛋白乙酰转移酶CBP, p300和PCAF/ GCN5，以及组蛋白脱乙酰酶HDAC1和SIRT1(NAD ${ }^{+}$依 赖的去乙酰化酶)都被募集到 $c c c D N A$ 上, 并且在HBV 复制中产生的HBx蛋白也被募集到 $c c c D N A$ 上，但是这 些蛋白被募集的先后顺序并不清楚. 他们进一步发现, 在不表达 HBx的HBV突变体的细胞中，虽然SIRT1和 HDAC1被正常募集到 $c c c D N A$ 上，但 $p 300$ 的募集受到 严重损害，最终导致cccDNA结合的组蛋白发生低乙酰 化, 从而使 $c c c D N A$ 转录的pgRNA也显著减少. 这些结 果表明，HBx能通过防止 cccDNA的去乙酰化而稳定 HBV复制. 此外, Deng等人 ${ }^{[29]}$ 报道, SIRT1可通过促进 转录因子以及共激活子的活性来激活 HBV 的转录, SRIT1可与HBx发生相互作用形成复合物，阻止蛋白被 降解; 同时复合物招募一些共激活的转录因子，促进 cccDNA的转录. 在这一过程中, SRIT1选择性对转录因 子去乙酰化, 如PGC- $1 \alpha$, 增强了 $\mathrm{HBx}$ 对于 $\mathrm{cccDNA}$ 的转 录激活. 文献也显示, SIRT1也调控P53, NF- $\mathrm{kB}, \mathrm{CREB}$, $\mathrm{E} 2 \mathrm{~F}$ 和p300等转录因子，同时 $\mathrm{HBx}$ 与一些转录因子有直 接或间接作用, 如P $53, \mathrm{NF}-\kappa \mathrm{B}, \mathrm{CREB}, \mathrm{c}-\mathrm{MYC}$ 和p 300 . 作 者认为, HBx能招募SIRT1到其作用的共转录因子附近, 通过表观遗传修饰发挥其功能，如促进cccDNA的转

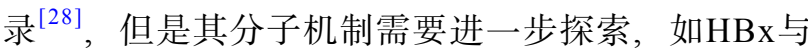
SRIT1如何相互作用、蛋白的泛素化修饰和稳定性等.

\subsection{HBx通过泛素化修饰影响HBV的复制}

在较早期就有关于HBx 与泛素化之间的关系研究. 比如有研究发现蛋白酶体PSMA7可以与HBx相互作 用，而PSMA7的结构域(氨基酸171-194)与HBx的互作 非常重要 ${ }^{[30]}$. 进一步的研究表明, HBx 通过其同源于 
Kunitz型的丝氨酸蛋白酶抑制剂的结构域与PSMA7和 PSMC1发生相互作用, 作者认为在自然状态下的 $26 \mathrm{~S}$ 蛋 白酶复合体中, PSMA7和PSMC1发生相互作用, 而HBx 与其中的一个蛋白相互作用后, 将会破坏PSMA7和 PSMC1的相互作用, 导致蛋白酶体复合物功能的改变, 这对于与 $\mathrm{HBx}$ 相互作用的转录共激活子来说至关重 要 ${ }^{[31]}$. 但是对于这推测, 还需要进一步去证明, 特别是 这些相互作用的功能. 另一较为清楚的研究是 $\mathrm{HBx}$ 与 DDB1(Damaged DNA binding protein 1)之间的相互作 用，以及它们在病毒感染和复制中的功能. 不管是 $\mathrm{WHV}^{[32]}$ 还是HBV ${ }^{[33]}$ ，DDB1蛋白对于病毒的复制是必 需的. DDB1是DDB复合物的一种亚基, 具有修复活性, 同时也是Cul4A-RING泛素E3连接酶(CRL4)的组分, 可 连接Cullin4A(Cul4A)和CUL4相关因子. 正常情况下, DDB1存在于胞质中, 当有UV照射造成细胞损伤时, 它 会逐渐移位到核内，而DDB的另一亚基DDB2对于 DDB1亚基在核内的积累是必要的，同时也对 $H B x$ 蛋白 的核内积累发挥重要的作用. DDB2通过异源二聚体结 构改变来影响 $\mathrm{HBx}$ 的稳定性, 而DDB1只通过直接作用 于HBx, 使其免遭蛋白酶体的降解. 在这一过程中, HBx 蛋白与DDB1的结合能极大限度地促进HBV复制, 但最 大化的HBV复制并不单一依赖于两者之间的结合，到 目前为止，其中许多精细机制仍然不十分清楚. 同时 $\mathrm{HBx}$ 与DDB1的结合可能要募集新的底物分子, 或是改 变由CRL4所调控的下游的信号通路 ${ }^{[34 ~ 36]}$. 而其中 HBx 对于 $S m c 5 / 6$ 的降解作用为此提供了一个重要的论证. 当 $\mathrm{HBV}$ 病毒感染人体细胞时, $\mathrm{HBV}$ 的基因组会到达宿 主的细胞核内, 这时宿主细胞核内的Smc5/6会对 HBV 的基因组进行识别，抑制HBV基因组的复制以及基因 的表达, 从而阻止了新病毒的产生. 但是病毒自身有其 自己的反击机制，也就是HBV病毒编码的HBx蛋白可 以识别并进一步结合 $\mathrm{Smc5} / 6$ 复合体，通过与DDB1CUL4-ROC1组成更大的复合体来诱导 $\mathrm{Smc5} / 6$ 的泛素 化而被其降解掉 ${ }^{[37,38]}$.

目前也有研究显示, HBx可以通过泛素化修饰调 控天然免疫信号中的多种重要蛋白分子来逃脱免疫反 应以促进HBV的稳定复制. 2015年的一篇报道揭示 HBV的pgRNA作为配体被RIG-I识别, 激活III型干扰素 反应从而诱导下游的抗病毒免疫反应和炎症反应 ${ }^{[39]}$. 而Wang等人 ${ }^{[40,41]}$ 报道HBx可以与MAVS蛋白结合并诱 导其降解，从而导致IFN- $\beta$ 减少，进而抑制I型干扰素信 号通路. 而几乎同时, Jiang和Tang ${ }^{[42]}$ 发现, HBx可以与
多种天然免疫信号蛋白如RIG-I，TRAF3和IRF3等相互 作用, 并切割其上Lys63连接的多聚泛素链, 从而抑制 $\mathrm{I}$ 型干扰素反应. 这些研究表明, HBx能直接靶向天然免 疫信号通路中的多个关键接头蛋白，或者与传递先天 免疫信号方面重要的分子, 通过泛素化修饰来间接或 直接干扰天然免疫反应对 HBV 的攻击, 从而实现免疫 逃逸以维持体内HBV稳定复制.

综上所述, $\mathrm{HBx}$ 可以通过不同修饰途径调控 $c c c D N A$ 转录进而影响HBV复制, 但关于HBx调节 $c c c D N A$ 活化 机制的研究还非常有限, 仍待进一步的探索.

\section{HBx通过miRNA来影响HBV DNA的复制}

microRNA是一类由约 22 个核苷酸组成的小型非 编码RNA, 作为基因表达调控的又一表观调控机制而 被逐渐认识. 最早发现与病毒转录本结合并抑制 HBV 基因表达和复制的miRNAs是miR-210, miR-199-3p和 miR-125a-5 $\mathrm{p}^{[43,44]}$, 这些研究结果让人们确信miRNA的 调控影响到了HBV的复制. 后来人们发现, HBV的复 制也能调控miRNA的表达, HBV感染过程中编码的各 个蛋白尤其是HBx均能调控miRNA的表达. 研究表明 $\mathrm{HBx}$ 主要从表观遗传修饰和转录水平来影响miRNA表 达. 研究者发现, HBx可上调DNMT1, DNMT3A1和 DNMT3A2的水平, 提高总DNA甲基转移酶(DNMT)的 活性从而影响miRNA启动子上 $\mathrm{CpG}$ 岛的超甲基化 ${ }^{[45]}$, 进而影响miRNA的表达, 这些被调控的miRNA可以通 过其靶标调控 HBV的复制. 同时, 许多研究表明, HBx 与众多著名的转录因子共同调节miRNA的表达，如 P53, c-Myc, CREB1等 ${ }^{[46 ~ 48]}$. 且进一步的研究发现, HBx 对miRNA的调控会极大程度地影响HBV的复制. 研究表明, HBV感染过程中, HBx引起的miR-122的下 调, 可增强HBV的复制能力, 同时诱导病毒的持续性感 染 ${ }^{[49 \sim 52]} .2014$ 年, Dai等人 ${ }^{[53]}$ 发现, miR-15b可以靶向肝 细胞核因子HNF1 $\alpha$ mRNA来减弱HNF1 $\alpha$ 的表达, 进一 步研究发现HBx蛋白抑制了 $\mathrm{miR}-15 \mathrm{~b}$ 的表达，形成了 $\mathrm{HBx} / \mathrm{miR}-15 \mathrm{~b} / \mathrm{HNF} 1$ 的正反馈环通路, 这一研究为 HBx 促进HBV稳定复制提供了新的机制解说. 同年有报道 发现, miR-125a可以结合到编码HBV膜囊蛋白(HBs) 的转录本上，干扰它的表达从而抑制了病毒的复制. 同时作者还发现，在肝癌细胞系中若过表达 $\mathrm{HBx}$, miR-125a的表达也同步提高. 因此，这就形成了一个 自我抑制的反馈通路，也即HBx可促进miR-125a的表 达, 而miR-125a又可作用与HBs的转录本上, 从而抑制 
了 $\mathrm{HBV}$ 的复制 ${ }^{[54]}$. 而本实验室发现在感染HBV的病人 血清中miR-192-3p与HBV DNA负相关; 进一步地, HBx 可下调miR-192-3p 的胞内表达与分泌，而这种下 调作用主要是通过 $\mathrm{HBx}$ 与转录因子 $\mathrm{c}-\mathrm{Myc}$ 的互作而作 用于 $m i R-192-3 p$ 的启动子; 更为重要的是 $H B V$ 可通过 HBX-miR-192-3p-XIAP轴来促进细胞的自噬进而促进 HBV 病毒复制 ${ }^{[48]}$. 近期有研究发现, 长链非编码RNA HULC 在激活HBV复制的同时可升高 $\mathrm{HBx}$ 的表达, HBx 与STAT3共同作用激活miR-539的启动子，而miR-539 可下调APOBEC3B的表达. 因此HULC可通过HBx/ STAT3/miR-539/APOBEC3B轴来激活HBV的复制 ${ }^{[55]}$. 尽管越来越多的证据表明, miRNA参与调控HBV复制, 但是许多过程和分子机制仍然不是很清楚，无论如何, 探索其对HBV复制, 特别是对 cccDNA转录的调控的分 子机制, 以miRNA为靶标, 设计针对小分子 miRNA的药 物, 将是治疗 HBV 相关疾病的一个极具潜在价值的 选择.

\section{4 总结与展望}

从HBV感染机体、在机体中的大量复制到诱发肝
脏炎症, 以致最后肝癌的发生发展, 是一个多步骤、多 阶段、多分子参与的过程 ${ }^{[56]}$. 在HBV诱导肝癌发生发 展的过程中, 从HBV自身出发, 通过两条主要的途径参 与调控: 第一, HBV自身的病毒DNA. 在病毒核酸发挥 功能时, 一方面是其核酸整合到宿主DNA中, 影响宿主 基因的表达, 特别是一些抑癌或促癌基因的表达; 另一 方面则是病毒合成cccDNA对机体造成持续性的感染， 第二，HBV合成的多种病毒蛋白，包括P蛋白、Core蛋 白、S蛋白以及X蛋白. 在这几种蛋白中, X蛋白对HBV 复制调控的研究是最多的, 且作用也是极其重要. HBx 可以作为反式作用因子, 调控相关基因的表达; 还参与 表观遗传修饰，比如甲基化、乙酰化、泛素化来影响 cccDNA的转录调控.

显然 $\mathrm{HBx}$ 不仅仅是在HBV病毒复制中具有重要的 作用，其在病毒持续感染、对机体产生炎症纤维化和 促机体致癌方面, 也有着重要作用. 但它无论是在HBV 复制, 还是在致病中的功能和机制仍然有许多未知, 因 此, 需要对HBx进行更深人功能和更详细机制的研究, 为将来更好地治疗 HBV 所引起的肝脏性疾病提供有效 的理论基础.

\section{参考文献}

1 Chen H S, Kaneko S, Girones R, et al. The woodchuck hepatitis virus X gene is important for establishment of virus infection in woodchucks. J Virol, 1993, 67: 1218-1226

2 Tang H, Delgermaa L, Huang F J, et al. The transcriptional transactivation function of HBx protein is important for its augmentation role in hepatitis B virus replication. J Virol, 2005, 79: 5548-5556

3 Slagle B L, Andrisani O M, Bouchard M J, et al. Technical standards for hepatitis B virus X protein (HBX) research. Hepatology (Baltimore, Md), 2015, 61: $1416-1424$

4 Dandri M, Petersen J, Stockert R J, et al. Metabolic labeling of woodchuck hepatitis B virus X protein in naturally infected hepatocytes reveals a bimodal half-life and association with the nuclear framework. J Virol, 1998, 72: 9359-9364

5 Hoare J, Henkler F, Dowling J J, et al. Subcellular localisation of the X protein in HBV infected hepatocytes. J Med Virol, 2001, 64: 419-426

6 Sirma H, Weil R, Rosmorduc O, et al. Cytosol is the prime compartment of hepatitis B virus X protein where it colocalizes with the proteasome Oncogene, 1998, 16: 2051-2063

7 Forgues M, Marrogi A J, Spillare E A, et al. Interaction of the hepatitis B virus X protein with the Crm1-dependent nuclear export pathway. J Biol Chem, 2001, 276: 22797-22803

8 Rahmani Z, Huh K W, Lasher R, et al. Hepatitis B virus X protein colocalizes to mitochondria with a human voltage-dependent anion channel, HVDAC3, and alters its transmembrane potential. J Virol, 2000, 74: 2840-2846

9 Zou L Y, Zheng B Y, Fang X F, et al. HBx co-localizes with COXIII in HL-7702 cells to upregulate mitochondrial function and ROS generation Oncol Rep, 2015, 33: 2461-2467

10 Zheng B Y, Fang X F, Zou L Y, et al. The co-localization of HBx and COXIII upregulates COX-2 promoting HepG2 cell growth. Int J Oncol, 2014 45: $1143-1150$

11 Li D, Chen Z X, Chen Y, et al. Location of the binding position for HBV X protein functional interaction with cytochrome C oxidase III (in Chinese). Chin J Hepatol, 2014, 22: 725-730 [李丹, 陈治新, 陈芸, 等. 乙型肝炎病毒X蛋白与细胞色素C氧化酶亚单位 III结合的定位研究. 中 华肝脏病杂志, 2014, 22: 725-730]

12 Liu B, Fang M, Hu Y, et al. Hepatitis B virus X protein inhibits autophagic degradation by impairing lysosomal maturation. Autophagy, 2014, 10: 416-430 
13 Nassal M. HBV cccDNA: Viral persistence reservoir and key obstacle for a cure of chronic hepatitis B. Gut, 2015, 64: 1972-1984

14 Tang H M V, Gao W W, Chan C P, et al. Requirement of CRTC1 coactivator for hepatitis B virus transcription. Nucleic Acids Res, 2014, 42: $12455-12468$

15 Gao Y, Feng J, Yang G, et al. Hepatitis B virus X protein-elevated MSL2 modulates hepatitis B virus covalently closed circular DNA by inducing degradation of APOBEC3B to enhance hepatocarcinogenesis. Hepatology (Baltimore, Md), 2017, 66: 1413-1429

16 Hayashi M, Deng L, Chen M, et al. Interaction of the hepatitis B virus X protein with the lysine methyltransferase SET and MYND domaincontaining 3 induces activator protein 1 activation. Microbiol Immunol, 2016, 60: 17-25

17 Werle-Lapostolle B, Bowden S, Locarnini S, et al. Persistence of cccDNA during the natural history of chronic hepatitis B and decline during adefovir dipivoxil therapy. Gastroenterology, 2004, 126: 1750-1758

18 Sung J J Y, Wong M L, Bowden S, et al. Intrahepatic hepatitis B virus covalently closed circular DNA can be a predictor of sustained response to therapy. Gastroenterology, 2005, 128: 1890-1897

19 Bowden S, Locarnini S, Chang T T, et al. Covalently closed-circular hepatitis B virus DNA reduction with entecavir or lamivudine. World J Gastroenterol, 2015, 21: 4644-4651

20 Wursthorn K, Lutgehetmann M, Dandri M, et al. Peginterferon alpha-2b plus adefovir induce strong cccDNA decline and HBsAg reduction in patients with chronic hepatitis B. Hepatology (Baltimore, Md), 2006, 44: 675-684

21 Xirong L, Rui L, Xiaoli Y, et al. Hepatitis B virus can be inhibited by DNA methyltransferase 3a via specific zinc-finger-induced methylation of the X promoter. Biochemistry (Mosc), 2014, 2014, 79: 111-123

22 Kostyushev D S, Zueva A P, Brezgin S A, et al. Overexpression of DNA-methyltransferases in persistency of cccDNA pool in chronic hepatitis B. Ter Arkh, 2017, 89: 21-26

$23 \mathrm{Fu}$ X, Song X, Li Y, et al. Hepatitis B virus X protein upregulates DNA methyltransferase 3A/3B and enhances SOCS-1CpG island methylation. Mol Med Rep, 2016, 13: 301-308

24 Ghosh K, Chatterjee B, Jayaprasad A G, et al. The persistent organochlorine pesticide endosulfan modulates multiple epigenetic regulators with oncogenic potential in MCF-7 cells. Sci Total Environ, 2018, 624: 1612-1622

25 Zhang W, Chen J, Wu M, et al. PRMT5 restricts hepatitis B virus replication through epigenetic repression of covalently closed circular DNA transcription and interference with pregenomic RNA encapsidation. Hepatology (Baltimore, Md), 2017, 66: 398-415

26 Benhenda S, Ducroux A, Rivière L, et al. Methyltransferase PRMT1 is a binding partner of HBx and a negative regulator of hepatitis B virus transcription. J Virol, 2013, 87: 4360-4371

27 Rivière L, Gerossier L, Ducroux A, et al. HBx relieves chromatin-mediated transcriptional repression of hepatitis B viral cccDNA involving SETDB1 histone methyltransferase. J Hepatol, 2015, 63: 1093-1102

28 Belloni L, Pollicino T, De Nicola F, et al. Nuclear HBx binds the HBV minichromosome and modifies the epigenetic regulation of cccDNA function. Proc Natl Acad Sci USA, 2009, 106: 19975-19979

29 Deng J J, Kong K Y E, Gao W W, et al. Interplay between SIRT1 and hepatitis B virus X protein in the activation of viral transcription. Biochim Biophys Acta Gene Regul Mech, 2017, 1860: 491-501

30 Huang J, Kwong J, Sun E C, et al. Proteasome complex as a potential cellular target of hepatitis B virus X protein. J Virol, 1996, 70: 5582-5591

31 Zhang Z, Torii N, Furusaka A, et al. Structural and functional characterization of interaction between hepatitis B virus X protein and the proteasome complex. J Biol Chem, 2000, 275: 15157-15165

32 Sitterlin D, Bergametti F, Tiollais P, et al. Correct binding of viral X protein to UVDDB-p127 cellular protein is critical for efficient infection by hepatitis B viruses. Oncogene, 2000, 19: 4427-4431

33 Leupin O, Bontron S, Schaeffer C, et al. Hepatitis B virus X protein stimulates viral genome replication via a DDB1-dependent pathway distinct from that leading to cell death. J Virol, 2005, 79: 4238-4245

34 Slagle B L, Bouchard M J. Role of HBx in hepatitis B virus persistence and its therapeutic implications. Curr Opin Virol, 2018, 30: 32-38

35 Nag A, Datta A, Yoo K, et al. DDB2 induces nuclear accumulation of the hepatitis B virus X protein independently of binding to DDB1. J Virol, 2001, 75: 10383-10392

36 Sugasawa K. UV-DDB: A molecular machine linking DNA repair with ubiquitination. DNA Repair, 2009, 8: 969-972

37 Decorsière A, Mueller H, van Breugel P C, et al. Hepatitis B virus X protein identifies the Smc $5 / 6$ complex as a host restriction factor. Nature, 2016, 531: 386-389

38 Murphy C M, Xu Y, Li F, et al. Hepatitis B virus X protein promotes degradation of SMC5/6 to enhance HBV replication. Cell Rep, 2016, 16: 2846-2854

39 Sato S, Li K, Kameyama T, et al. The RNA sensor RIG-I dually functions as an innate sensor and direct antiviral factor for hepatitis B virus. Immunity, 2015, 42: 123-132

40 Wang X, Li Y, Mao A, et al. Hepatitis B virus X protein suppresses virus-triggered IRF3 activation and IFN- $\beta$ induction by disrupting the VISA- 
associated complex. Cell Mol Immunol, 2010, 7: 341-348

41 Wei C, Ni C, Song T, et al. The hepatitis B virus X protein disrupts innate immunity by downregulating mitochondrial antiviral signaling protein. J Immunol, 2010, 185: 1158-1168

42 Jiang J, Tang H. Mechanism of inhibiting type I interferon induction by hepatitis B virus X protein. Protein Cell, 2010, 1: 1106-1117

43 Zhang G, Li Y, Zheng S, et al. Suppression of hepatitis B virus replication by microRNA-199a-3p and microRNA-210. Antiviral Res, 2010, 88: 169-175

44 Potenza N, Papa U, Mosca N, et al. Human microRNA hsa-miR-125a-5p interferes with expression of hepatitis B virus surface antigen. Nucleic Acids Res, 2011, 39: 5157-5163

45 Zhang T, Zhang J, Cui M, et al. Hepatitis B virus X protein inhibits tumor suppressor miR-205 through inducing hypermethylation of miR-205 promoter to enhance carcinogenesis. Neoplasia, 2013, 15: 1282-IN26

46 Xu X, Fan Z, Kang L, et al. Hepatitis B virus X protein represses miRNA-148a to enhance tumorigenesis. J Clin Invest, 2013, 123: 630-645

47 Zhou S J, Deng Y L, Liang H F, et al. Hepatitis B virus X protein promotes CREB-mediated activation of miR-3188 and Notch signaling in hepatocellular carcinoma. Cell Death Differ, 2017, 24: 1577-1587

48 Wang J, Chen J, Liu Y, et al. Hepatitis B virus induces autophagy to promote its replication by the axis of miR-192-3p-XIAP through NF kappa B signaling. Hepatology, 2019, 69: 974-992

49 Bandopadhyay M, Sarkar N, Datta S, et al. Hepatitis B virus X protein mediated suppression of miRNA-122 expression enhances hepatoblastoma cell proliferation through cyclin G1-p53 axis. Infect Agents Cancer, 2016, 11: 40

50 Yu G, Chen X, Chen S, et al. miR-19a, miR-122 and miR-223 are differentially regulated by hepatitis B virus X protein and involve in cell proliferation in hepatoma cells. J Transl Med, 2016, 14: 122

51 Liang H W, Wang N, Wang Y, et al. Hepatitis B virus-human chimeric transcript HBx-LINE1 promotes hepatic injury via sequestering cellular microRNA-122. J Hepatol, 2016, 64: 278-291

52 Wang S, Qiu L, Yan X, et al. Loss of microRNA 122 expression in patients with hepatitis B enhances hepatitis B virus replication through cyclin G (1)-modulated p53 activity. Hepatology (Baltimore, Md), 2012, 55: 730-741

53 Dai X, Zhang W, Zhang H, et al. Modulation of HBV replication by microRNA-15b through targeting hepatocyte nuclear factor $1 \alpha$. Nucleic Acids Res, 2014, 42: 6578-6590

54 Mosca N, Castiello F, Coppola N, et al. Functional interplay between hepatitis B virus X protein and human miR-125a in HBV infection. Biochem Biophys Res Commun, 2014, 449: 141-145

55 Liu Y, Feng J, Sun M, et al. Long non-coding RNAHULC activates HBV by modulating HBx/STAT3/miR-539/APOBEC3B signaling in HBVrelated hepatocellular carcinoma. Cancer Lett, 2019, 454: 158-170

56 Xu W, Yu J, Wong V W S. Mechanism and prediction of HCC development in HBV infection. Best Pract Res Clin Gastroenterol, 2017, 31: 291298 


\title{
The regulation of $\mathrm{HBx}$ in hepatitis $\mathrm{B}$ virus replication
}

\author{
Yandan Guo ${ }^{1}$, Jingwen Wang ${ }^{1}$, Sen Yuan ${ }^{1}$, Shuting Guo ${ }^{1}$, Dan Liu ${ }^{1}$ \& Guihong Sun ${ }^{1,2 *}$ \\ ${ }^{1}$ School of Basic Medical Sciences, Wuhan University, Wuhan 430072, China; \\ ${ }^{2}$ Hubei Province Key Laboratory of Allergy and Immunology, Wuhan 430072, China \\ * Corresponding author, E-mail: ghsunlab@whu.edu.cn
}

Hepatocellular carcinoma (HCC) is one of the most aggressive human malignancies in the world, which has been proven to be highly associated with a background of chronic and persistent infection of hepatitis B virus(HBV). HBV is an enveloped, partially double-stranded DNA virus that belongs to the Hepadnaviridae family of viruses. The level of HBV replication in a chronically HBV-infected individual can vary throughout the infection, and the rise and fall of HBV replication during chronic infection may affect disease progression. In the process of HBV infection, the replication of HBV DNA, the synthesis of viral proteins ( $\mathrm{HBp}, \mathrm{HBc}, \mathrm{HBs}, \mathrm{HBx}$ ), and the packaging and releasing of new virus particles are performed. HBx protein is translated from HBx mRNA which transcribed by cccDNA and has a total length of 154 amino acids. Based on a brief description of the structure and distribution of HBx protein, the effects of HBx on HBV replication are reviewed.

Once HBV infection of hepatocytes cell, the viruses first bind to receptors on the cell membrane, following by entering the cytoplasm in a manner similar to transportation of vesicles, then the viral removed the envelope and genome DNA is transferred into the nucleus. The DNA through the repairing mechanism generates cccDNA, which is transcribed and translated into viral mRNAs and proteins whose finally are packaged together to form new viral particles. It can be seen that the generation of cccDNA is the key for the replication of viral DNA and the formation of persistent infection. cccDNA exists in the nucleus independently of genomic DNA, but it is similar to genomic DNA and binds a large number of histones and non-histones, which are regulated by a variety of epigenetics such as methylation, acetylation and ubiquitination, to affect the transcription efficiency of cccDNA.

Until now, the molecular mechanisms related to HBV replication and associated liver diseases have not been well understood. Currently, cumulative evidence indicates that the methylation, acetylation, and ubiquitination have vital roles in HBV replication as well as virus-related pathogenesis. This review aims to summarize advances in the study of HBx in terms of regulating the HBV replication through its mediating protein methylation, acetylation, deacetylation and ubiquitination. At the same time, miRNAs also play an important role in the regulation of HBx on HBV DNA replication. miRNAs are a type of small regulatory RNAs that consist of about $22 \mathrm{nt}$ nucleotides and can not be translated into proteins. In organisms, miRNA involves in a variety of life activities and plays a role of the regulation of complementary mRNA at the post-transcription level. It is identified that HBx can regulate viral DNA replication by influencing the expression of target genes through miR-122, miR-15b, miR-125a, miR-192-3p, miR-539 and so on. However, HBx, acting as transactivating factors, interacts with transcription factors to regulate the transcription of miRNAs. These transcription factors mainly include TBP, NF-kB, P53, c-Myc, CREB1 and so on.

To sum up, we review the mechanism of HBx on HBV replication to provide ideas for the accurate diagnosis and treatment of HBV-induced hepatocellular carcinoma.

\section{HBx, HBV replication, cccDNA, miRNA}

doi: 10.1360/N972019-00351 